\title{
Radiocarbon
}

1992

\section{ISOTOPE DATING OF PLEISTOCENE DUNG DEPOSITS FROM THE COLORADO PLATEAU, ARIZONA AND UTAH}

\author{
JIM I. MEAD $D^{1}$ and LARRY D. AGENBROAD
}

Department of Geology and Quaternary Studies Program, Box 6030, Northern Arizona University Flagstaff, Arizona 86011 USA

\begin{abstract}
Identified dung and keratinous remains of large mammals are considered the most reliable materials to ${ }^{14} \mathrm{C}$ date, when the initial question includes the application of the date to the time of local extirpation and extinction. The Colorado Plateau provides a unique preservation habitat (desiccation), found in greater abundance of deposits than anywhere else in North America. We review 20 localities from the Colorado Plateau that contain dung of megaherbivores. Seven species of herbivores were identified utilizing dung: Bison (bison), Equus (horse), "Euceratherium" (shrubox), Mammuthus (mammoth), Nothrotheriops (ground sloth), Oreamnos (mountain goat) and Ovis (bighorn), and $79{ }^{14} \mathrm{C}$ dates were measured from the sites. Most sites contain additional associated ${ }^{14} \mathrm{C}$ and $\mathrm{U} / \mathrm{Th}$ dates on skeletal and botanical remains.
\end{abstract}

\section{INTRODUCTION}

This article is about ${ }^{14} \mathrm{C}$ dating of dried dung recovered from alcoves and caves on the Colorado Plateau of Arizona and Utah. Beyond the significance of the dung as a paleontological curiosity, the broader issue is that these remains provide high-quality organic residues for ${ }^{14} \mathrm{C}$ results. When the dung is identified to the generic or specific level, the perishable remains become a valuable tool for exploring the timing and possibly the reasons for late Wisconsin extinctions and extirpations in southwestern USA. Dung contents of extinct Pleistocene herbivores are found predominately in two regions: Holarctic permafrost (e.g., Siberia and Alaska), or dry caves in Southwest USA (although portions of Mongolia, China and Australia might also be included in the near future). Large and small animals enter shelters, such as alcoves and caves, for a variety of reasons. During the time of their stay within the shelter, the animals often leave behind tissue remains (hair and keratin), or they may die, leaving muscle, hide and bone. More often, they will deposit dung. The arid environment outside of, and the hyperarid situation within the shelter that has persisted for more than $40 \mathrm{ka}$, preserves the organic remains by desiccation or extreme dehydration.

Although often common when found in a particular site, dung deposits are unusually rare in the Southwest. Desiccated Pleistocene dung has been found in caves in the Basin-and-Range regions of Arizona, Nevada, New Mexico, Texas and Utah. The deposits are small and the localities are few, compared to the shelters that have been studied on the Colorado Plateau, mostly since 1983 (Fig. 1). The dry, flat-lying Paleozoic and Mesozoic sedimentary formations of northern Arizona, eastern Utah, western Colorado and northwestern New Mexico have provided a unique setting for caves and alcoves that have preserved numerous late Pleistocene (upper Rancholabrean, terminal Wisconsin Glacial) organic deposits.

${ }^{1}$ Also, San Bernardino County Museum, Redlands, California 92374 USA 


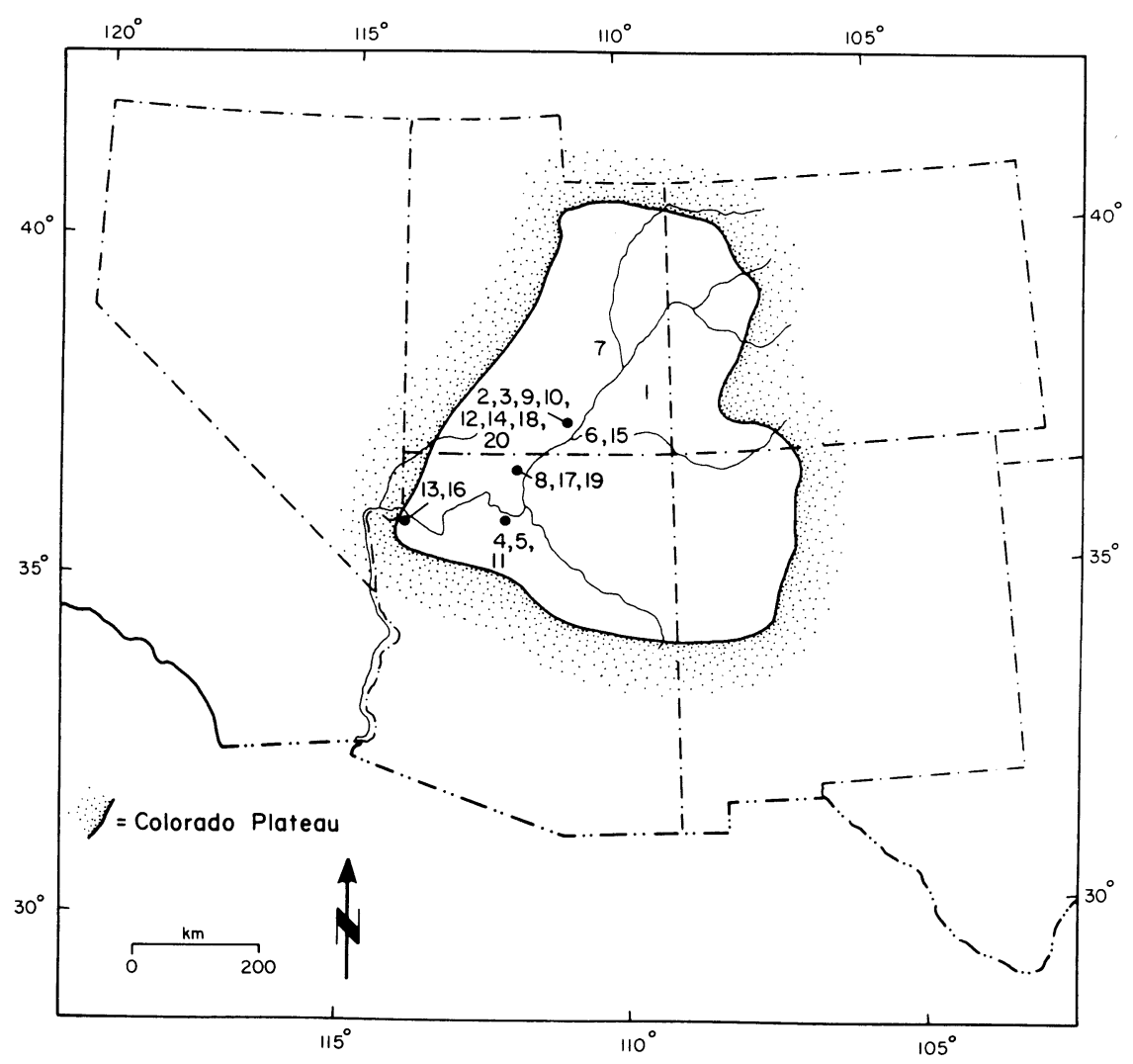

Fig. 1. Map of the Colorado Plateau illustrating general locations of sites discussed in the text

Dried dung has largely gone unappreciated for its potential accuracy of ${ }^{14} \mathrm{C}$ analysis and availability of other data resources. Few remains of animals are more critical to ${ }^{14} \mathrm{C}$ dating for the purpose of succinctly analyzing a species of extinct megaherbivore than the specimens of identifiable and preserved dung (Meltzer \& Mead 1985). Analysis of dung deposited by extinct or extirpated megafauna in the Southwest began with Lull's (1930) description of the ground sloth (Nothrotheriops) boluses found in Rampart Cave, Grand Canyon National Park. But not until Martin, Sabels and Shutler's (1961) detailed examination of the dung deposits for clues to megafaunal extinction, did the analysis of feces become an integral part of paleoecological reconstructions in the arid Southwest.

Paramount to the usefulness of Pleistocene dung is the identification of the producer. The more unusual morphologies are readily identifiable. Martin, Sabels and Shutler (1961) have provided criteria for the identification of Nothrotheriops shastensis (Shasta ground sloth) dung boluses. The unusually large contents and overall size of elephant dung, such as Mammuthus (mammoth), is characterized in Hansen (1980), Davis et al. (1984) and Mead et al. (1986a).

The pellet-producing herbivores provide problematic identifications. Cervids (deer) and most bovids (cattle, sheep, etc.) produce pellets of dung with little apparent morphological differences. Large cuboid pellets recovered from caves in the Grand Canyon were identified as Oreamnos harringtoni (Harrington's mountain goat), following the criteria in Robbins, Martin and Long (1984) and Mead, 
O'Rourke and Foppe (1986). These large pellets are typically found in caves in rough terrain, associated with skeletal remains of only $O$. harringtoni. The sandstone alcoves in the Glen Canyon and Canyonlands regions north of the Grand Canyon are in less rugged terrain, permitting additional less agile pellet-producing species to use the same shelter as Oreamnos. Here, the identification of the pellet producers is less reliable. Because of this problem, Mead, Theis and Agenbroad (ms.) are now developing criteria using nuclear magnetic resonance (NMR) of bile acids to provide a biochemical "signature" for identifying the various dung morphologies.

A large dung pellet (significantly larger than that of Oreamnos harringtoni) is being recovered consistently from the easily accessible sandstone shelters in Utah. These pellets were found in loose association with a tooth of Euceratherium collinum (shrubox), the only skeletal remains of a large mammal found during the excavation in Bechan Cave. These large pellets have an external morphology similar to the pellets of Ovibos moschatus (living muskox) and Symbos (extinct muskox; frozen carcass remains). In this article, we refer these unique pellets to "Euceratherium," until our NMR results are final.

Here we provide a review and update of radiocarbon-dated dung remains and their localities on the Colorado Plateau, reported in a wide array of publications by various researchers since 1961 . We collected and studied the material at 15 of the 20 localities published about the Colorado Plateau. An asterix $\left({ }^{*}\right)$ in front of the locality name indicates the sites at which one or both of us have investigated the organic remains. The number preceding the asterix provides the numbered location in Figure 1.

Many of the sediments forming the loose-to-weakly compacted alcove fill are derived from eolian deposition, evaporite crystal exfoliation and cliff spall clasts. Excavation of these sites without a great deal of broadside digging and shoring is often prohibitive in the loose sediments, due to slumpage. Thus, we usually removed material on the exposed erosional slope angle (Fig. 2). These deposits are relatively loose, with an angle of repose of $\sim 30^{\circ}$ to $36^{\circ}$. Once a particular organic unit was found, its in-situ position was verified by limited test excavation and its remains collected. We recorded dung (and other organic specimens) by depth below the horizontal surface of the deposit in the shelter. The dated samples included here are all plant tissues removed from the dung of extinct herbivores, and as such, provide a tight temporal association between herbivore producer, plant species ingested and local floral community. All dates are reported in years before present (BP) (AD 1950), using the Libby half-life of 5568 years.

Most of the published dung sites are on lands administered by the National Park Service (NPS). This agency has indicated that, in order to help protect these deposits, we should not locate the sites on a map. Figure 1 is a generalized map illustrating the approximate location of the dung sites discussed in the text. This map is solely for an overall appearance of the locations. The sensitivity of these dry dung sites by us and the NPS is justified in view of the 1976 destruction by fire of the organic layers in Rampart Cave, Grand Canyon. This sort of needless ruin of non-renewable fossils must not happen again. Any researcher desiring exact location data should contact the Regional Scientists of either the Rocky Mountain or Western regional offices of the NPS. Locality and NPS accession numbers are indicated for many sites, usually those containing materials curated into the NPS Repository at the Laboratory of Quaternary Paleontology, Quaternary Studies Program, Northern Arizona University, Flagstaff.

We use the following abbreviations: BLM - Bureau of Land Management; GLCA - Glen Canyon National Recreational Area; GRCA - Grand Canyon National Park (GCNP, an old designation still used with some of the older curated material); NPS - National Park Service; NABR - Natural 


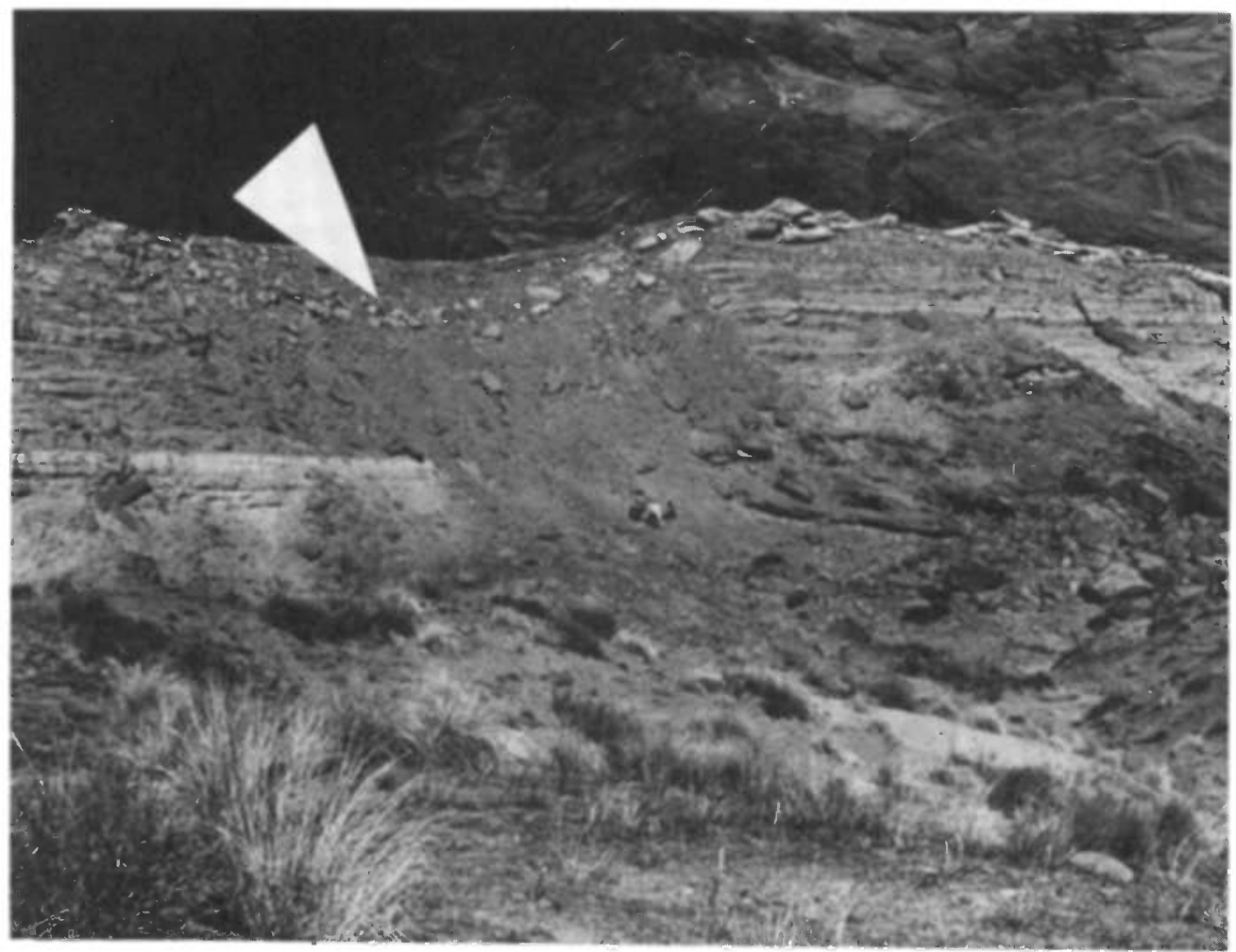

Fig. 2. Grobot Grotto. Note people in middle for scale of deposit. Stratified fluvial units in the lower sections of the profile are dating to the Sangamonian Interglacial, based on thermoluminescence (TL) analyses. Stratified eolian and spall sediments containing macrobotanical and dung remains occur immediately below and predominantly above the large rockfall "smile" (see arrow) in the upper portion of the picture. Beta-14422. lie- immediately below and touching the large rockfall, smile, layer.

Bridges National Monument; and QSP - Quaternary Studies Program, Northern Arizona University. Laboratories include: A - Arizona; AA - Arizona Accelerator; Beta - Beta Analytic Inc.; GX - Geochron Laboratories; L - La Jolla; RL - Radiocarbon Limited.

\section{1. ${ }^{*}$ Bare Ladder Shelter}

This alcove (NAU QSP site 8710; NPS NABR) is located in the Cedar Mesa Sandstone at 1830 $\mathrm{m}$ elevation (10 $\mathrm{m}$ above the present alluvial terrace), White Canyon, Natural Bridges National Monument, Utah. Remnant deposits including dung and packrat middens are common in the protected crevices in the back of the wide shelter (Mead et al. 1987). Dung and packrat midden data, reported here, come from a $100-\mathrm{cm}$ profile. Although in entire pellet form, the dung was becoming friable in the lower level, and thus was not pretreated with $\mathrm{NaOH}$. Twenty pellets from each unit were measured and cut in half; 20 halves were used for dating; the other halves were used for microhistology. Mead et al. (1987) provide measurements and microhistological data from the dung pellets.

\section{GX-11312. Oreamnos harringtoni}

$>39,800$

Pellets from Layer 0, basal level in the $100-\mathrm{cm}$ profile.

$\delta^{13} \mathrm{C}=-25.2 \%$ 。 


\section{GX-11313. Oreamnos harringtoni}

Pellets from Layer 2.

$\delta^{13} \mathrm{C}=-26.0 \%$

Comment: Additional ${ }^{14} \mathrm{C}$ dates from the site include a birch (Betula) twig (GX-11594, 26,470 $+740 /-680$; assumed to be an introduced contaminant) and packrat middens (Layer 3, Beta-14418, $21,330 \pm 240$; Layer 5, Beta-14419, $9660 \pm 160$ ).

\section{2. * Bechan Cave}

Bechan Cave (NAU QSP site 872; NPS GLCA Accession 81) is a large sandstone grotto at 1280 $\mathrm{m}$ elevation. The single-room cavern is $\sim 52 \mathrm{~m}$ long, $31 \mathrm{~m}$ wide and $9 \mathrm{~m}$ high. With a southwestfacing entrance, the room stays well lit during the daytime. Numerous test excavations, corings and analyses were made to determine the morphology and character of the dung deposit (Agenbroad et al. 1989; Davis et al. 1984, 1985; Martin 1987; Mead \& Agenbroad 1989; Mead et al. 1984, 1986a).

The upper unit of the deposit contains a layer of roof spall and eolian sand mixed with cultural materials (Agenbroad et al. 1989). Sand comprises the lowest unit tested. The middle unit is a layer of organic remains, composed predominantly of dung, mostly derived from the mammoth (Mammuthus columbi). Most of the large dung is fragmented, however, several entire boluses and numerous plant remains are common. Initially, it was assumed that whatever was recovered from the dung unit must have been part of a mammoth bolus and thus a segment of its diet (Davis et al. 1984, 1985). Subsequently, we have determined that at least eight different dung morphologies can be recognized in the organic unit, including the following: cottontail rabbit (Sylvilagus), mammoth, shrubox ("Euceratherium collinum"), packrat (Neotoma), Shasta ground sloth (Nothrotheriops shastensis), bighorn sheep (Ovis canadensis), cf. mountain goat (Oreamnos harringtoni) and possibly, horse (Equus).

A-3212. Mammuthus

Fragment of M1 bolus.

A-3213. Mammuthus

Fragment of M2 bolus.

A-3296. Mammuthus

Fragment of M3 bolus.

A-3297. Mammuthus
$11,670 \pm 300$

$\delta^{13} \mathrm{C}=-23.2 \% 0$

$12,900 \pm 160$

$\delta^{13} \mathrm{C}=-23.2 \%$

$11,850 \pm 160$

$\delta^{13} \mathrm{C}=-25.7 \%$

$12,400 \pm 250$

$\delta^{13} \mathrm{C}=-21.9 \%$

Predominantly mammoth dung fragmented bolus, but possibly also contains other organic remains.

A-3298. Mammuthus

$12,620 \pm 220$

Fragment of M4 bolus.

$\delta^{13} \mathrm{C}=-18.4 \%$ 
The following 14 samples are single plant remains removed by O. K. Davis and P. S. Martin, Desert Laboratory, The University of Arizona, Tucson, from single mammoth dung boluses or bolus fragments that we collected during our initial excavation. AA samples were dated using accelerator mass spectrometry (AMS) by the NSF-Arizona Facility for Radioisotope Analysis.

AA-1109. Grass culms

AA-1110. Atriplex

AA-1111. Grass culms

AA-1112. Atriplex

AA-1113. Grass culms

AA-1114. Sedge achenes

AA-1116. Grass culms

AA-1117. Atriplex

AA-1119. Grass culms

AA-1120. Grass culms

AA-1121. Atriplex

AA-1122. Sedge achenes

AA-1123. Grass culms

AA-1124. Atriplex

Beta-18269. "Euceratherium"

A spring-green mass containing pellet forms.

GX-9371. Mammuthus

$13,505 \pm 580$

A fragmented bolus with possibly other organic remains.

Comment: A dated twig of oak (Quercus) recovered loose from the organic unit indicates that the plant remains were deposited before the beginning of most of the megafaunal dung deposit (A-3514, 16,700 \pm 250 , Davis et al. 1985).

\section{3. ${ }^{*}$ BF Alcove}

BF Alcove (NAU QSP site 877; NPS GLCA Accession 82) faces north at $1204 \mathrm{~m}$ elevation, with a wide shelter entrance containing a narrow $(8 \mathrm{~m})$ deposit preserved within the dripline $(72 \mathrm{~m}$ above modern streambed base level). Most of the alcove is filled with laminated fluvial sediments, overlain by a thin veneer of dry eolian loose sand at the top ( 8 by $16 \mathrm{~m}$ ). Douglas fir (Pseudotsuga 
menziesii) needles and maple (Acer spp.) were associated with two dung pellets that appear to be as large as a camel's (Camelops). No dates were directly measured on the dung pellets. Beta-14727, 11,790 \pm 190 , dates Douglas fir and maple needles and seeds; another Douglas fir sample (Beta-20995) dates to $12,130 \pm 170$ BP. Withers (1989) and Withers and Mead (ms.) discuss these plant remains.

\section{4. * Bida Cave}

Bida Cave (NAU QSP site 919; NPS GRCA Accession 4597) is a limestone grotto with a large lower entrance room at $1430 \mathrm{~m}$ elevation, containing numerous surface remains of the extinct mountain goat (Oreamnos harringtoni). Cole $(1981,1982,1990)$ and Cole and Mead (1981) discussed the packrat middens recovered from the cave. Test-pit excavations yielded a multitude of faunal and floral remains. Mead et al. (1986b) discussed the ${ }^{14} \mathrm{C}$ dates of the hornsheaths of the extinct Harrington's mountain goat.

\section{A-2373. Oreamnos harringtoni}

$24,190_{-2800}^{+4300}$

Four dung pellets from Layer 8 in test pit 9 N00 were measured for identification and then sectioned for ${ }^{14} \mathrm{C}$ dating and microhistological (dietary) content analyses.

RL-1133. Oreamnos harringtoni

$13,100 \pm 700$

Dung pellets were recovered on the surface next to the skull of $O$. harringtoni (GCNP 21974). The hornsheath from the skull dated to $12,930 \pm 110$ (SI-3988). Pellets were measured for identification and then sectioned for ${ }^{14} \mathrm{C}$ dating and microhistological content analyses.

\section{RL-1134. Oreamnos harringtoni}

$11,850 \pm 750$

Dung pellets were removed from a ground depression used for sleeping located on the surface at the back of the entrance room adjacent to the point of total darkness (Mead 1983). Pellets were measured for identification and then sectioned for ${ }^{14} \mathrm{C}$ dating and microhistological content analyses.

\section{RL-1135. Oreamnos harringtoni}

$16,150 \pm 600$

Pellets were removed from Layer 4 in test pit 9N00. Pellets were measured for identification and then sectioned for ${ }^{14} \mathrm{C}$ dating and microhistological content analyses.

\section{5. * Chuar Cave}

Chuar Cave is an inadequately understood cave in GRCA.

Beta-28791. Oreamnos harringtoni

$29,380 \pm 990$

Pellets and amalgamated dung mat layer.

\section{6. * Cottonwood Alcove}

Cottonwood Alcove (our name for archaeological site 42SA20858; GLCA) measures $160 \mathrm{~m}$ by 15 $\mathrm{m}$ on a south-facing aspect ( $75 \mathrm{~m}$ above the present streambed), and is located at $1195 \mathrm{~m}$ elevation. This sandstone alcove was visited in the late 1980s by archaeologists on a survey of Anasazi cultural remains. The surface area of the alcove contains large dung pellets eroding out of the talus slope, similar to that found in Grobot Grotto and Hooper's Hollow (see below), and in sediments 
removed by the Anasazi and tossed down the slope. The site has not been excavated or tested (P. Geib, personal communication). Isolated dung pellets were collected by Phil Geib, Northern Arizona University, and given to us for ${ }^{14} \mathrm{C}$ and morphometric analyses.

Beta-28790. "Euceratherium"

$12,510 \pm 190$

Parts of two pellets, halved after measurements; $0.5 \mathrm{gm} \mathrm{C}$ was given extended counting time.

\section{Cowboy Cave}

Cowboy Cave is a large single-room grotto in sandstone on land administrated by the BLM. Most of its sediments contain archaeological material of Archaic age, however, the lowest layers contain Pleistocene dung. Jennings (1980) described five sedimentary units in the cave, the lowest (I) divided into two subunits. ${ }^{14} \mathrm{C}$ ages range from 13 to $0.5 \mathrm{ka} \mathrm{BP}$. Unit $\mathrm{Ib}$ is an organic mat similar to that found in Bechan Cave, but composed predominantly of Bison (not Mammuthus) dung. Hansen (1980: 182) ascribed the fragmented remains of dung to both living and extinct species of late Pleistocene megafauna - elk, elk-camel, elephant, horse, and Shasta ground sloth. Many of these remains are being reanalyzed by nuclear magnetic resonance.

\section{A-1653. Herbivore}

$12,070 \pm 210$

This dung sample is unidentified, but it is probably disaggregated Bison dung boluses. It was collected by associates at the Desert Laboratory, The University of Arizona.

A-1654. Herbivore

$13,040 \pm 440$

See description of A-1653, above.

\section{A-1800. Herbivore}

$12,320 \pm 160$

See description of A-1653, above.

\section{UGa-636. Herbivore}

See description of A-1653, above. This sample was collected during preliminary excavations (Jennings 1980).

\section{8. * Disappearing Cave}

Disappearing Cave is a small limestone shelter opening out onto the Marble Canyon region of GRCA. Much of the entrance area is exposed and eroding. A small stratified section of sediments, plant remains and dung pellets is still in existence.

Beta-28792. Oreamnos harringtoni

$27,360 \pm 960$

Dung pellets were removed from the surface of a mat unit.

\section{9. * Grobot Grotto}

Grobot Grotto (NAU QSP site 878; NPS GLCA Accession 82) is a south-facing shelter at 1189 $\mathrm{m}$ elevation. This large alcove (Fig. 2) consists of $6 \mathrm{~m}$ of stratified eolian sand and roof spall with interspersed layers of dung and leaf-litter matting. Because of the extremely loose sand units, the stratified units were not formally excavated, although the layers on the slope exposure have been 
studied in detail (Withers 1989; Withers \& Mead, ms.). Numerous coprolite remains are known from the site, but only Mammuthus, Bison and "Euceratherium" were dated directly. Cf. Ovis and cf. Oreamnos were also dated by association with the ${ }^{14} \mathrm{C}$ dates. Overlying Holocene units yielded the following ${ }^{14} \mathrm{C}$ ages: Beta-20997: $9920 \pm 100$, wood; Beta-20998: $9730 \pm 170$, wood, $0.5 \mathrm{gm}$ $C$ used for extended counting; Beta-20999: $7510 \pm 160$, wood $0.4 \mathrm{gm} \mathrm{C}$ used for extended counting (Withers 1989; Withers \& Mead, ms.).

Beta-14420. "Euceratherium"

$20,930 \pm 400$

Isolated pellets from on the slope of the profile.

Beta-14422. Mammuthus

$28,290 \pm 2100$

A dung bolus from the slope.

Beta-20996. Mammuthus

$26,140 \pm 670$

A dung bolus from slope depth, $10.1 \mathrm{~m} .0 .7 \mathrm{gm} \mathrm{C}$ used for extended counting.

Beta-22999. Bison

$15,270 \pm 120$

A single bolus from slope depth, $3 \mathrm{~m}$.

Beta-23322. "Euceratherium"

$18,320 \pm 290$

Pellets from slope depth, $3.48 \mathrm{~m}$.

\section{0. * Hooper's Hollow}

Hooper's Hollow (NAU QSP site 873; NPS GLCA Accession 82) is a wide, south-facing alcove at $1204 \mathrm{~m}$ elevation, just upstream from Grobot Grotto (Agenbroad \& Mead 1987). Typical of the canyon, laminated fluvial sediments choke most of the alcove, and eolian material and cliff spall comprise the upper 2-4 m of deposit. Many organic layers lie within these upper units. Other ${ }^{14} \mathrm{C}$ dates derived from the upper deposits include a packrat midden (Beta-23710: 13,110 \pm 100 ) and oak twigs (Beta-25412: 10,630 \pm 110; Beta-25411: 12,010 \pm 110 ). In addition to the dated Bison dung, "Euceratherium" and cf. Ovis are dated by association. A single bone element of Oreamnos harringtoni was recovered from a deflated and unprovenienced locus at the site. More detailed analysis of the stratified units and their contents are needed.

Beta-23323. Bison

$18,840 \pm 350$

This sample is from a single, large, complete dung bolus of pie consistency and shape. Mead and Agenbroad (1989) provide dietary data.

\section{1. * Kaetan Cave}

This site (NAU QSP site 9117; NPS GRCA Accession 4597) is a medium-sized limestone cave at $1430 \mathrm{~m}$ elevation with an eastern orientation. The deposit in the cave was first excavated for split-twig figure archaeology (Schwartz, Lange \& DeSaussure 1958). Mead (1983) excavated portions of the deposit in the entrance room for remains of Oreamnos harringtoni (Mead, O'Rourke \& Foppe 1986; O'Rourke \& Mead 1985). McVickar and Mead are preparing a manuscript on paleoenvironmental reconstruction based on macrobotanical remains recovered from packrat middens and stratified sediments of this site. 
Surface sample, composite of 10 pellet halves.

A-2722. Oreamnos harringtoni

$30,600 \pm 1800$

Level 6 in test pit 1, matted dung layer with some whole pellets.

A-2723. Oreamnos harringtoni

Level 3 in test pit 1, matted dung layer with many whole pellets.

\section{A-2835. Oreamnos harringtoni}

$14,220 \pm 320$

Level 1 in test pit 1 , whole pellets isolated in sediments.

\section{2. * Mammoth Alcove}

Mammoth Alcove (NAU QSP site 875; NPS GLCA Accession 82) is a medium-sized shelter, contained in a perched, bedrock meander bend. Like the other shelters, Mammoth Alcove, at 1188 $\mathrm{m}$ elevation on a south-southeast exposure, contains laminated lacustrine and fluvial sediments characteristic of other canyon alcoves. At the base of this sedimentary sequence, we recovered the remains of a mammoth skeleton. We also recovered dung boluses of Mammuthus, Bison, and $c f$. Ovis overlying the skeleton, in the eolian and roof spall units.

Beta-20705. Mammuthus

$16,630 \pm 280$

This sample is a portion of a larger mammoth dung bolus fragment that was deflating out of loose-to-slightly compacted sand at the horizontal surface in the alcove. We feel that this date is stratigraphically correct.

Comment: The whole bone fraction of mammoth bone was dated (Beta-20704, 10,505 \pm 260$)$. We believe that the date is erroneous, based on inherent problems with whole bone fraction dates, and the dung date (Beta-20705), recovered well above the skeleton. A vertebra from the same skeleton was dated by U/Th: 19,300 \pm 600 (Richard Ku, University of Southern California). The sample had a low ${ }^{232} \mathrm{Th}$ concentration, and thus, a large ${ }^{230} \mathrm{Th} /{ }^{232} \mathrm{Th}$ ratio. We did not obtain a ${ }^{231} \mathrm{~Pa} /{ }^{235} \mathrm{U}$ crosscheck analysis; however, we assume that this U/Th date is correct and reject Beta-20704, the ${ }^{14} \mathrm{C}$ date.

\section{Muav Caves}

These caves (GRCA) are a series of three small north-facing solution tubes in the Muav Limestone, at $426 \mathrm{~m}$ elevation, which coalesce with their sedimentary floor deposits at their entrances. Sporadic examinations were made and test pits dug, but no formal excavation was made. Most analyses have centered on the Nothrotheriops dung (Long \& Martin 1974; Long, Hansen \& Martin 1974; Martin, Thompson \& Long 1985; Mead \& Agenbroad 1989). Specimens of the dung are stored at the Department of Geosciences, The University of Arizona. All samples were apparently recovered from the surface.

\section{A-1212. Nothrotheriops shastensis}

$11,140 \pm 160$

Single dung bolus. 
A-1213. Nothrotheriops shastensis

$11,290 \pm 170$

Single dung bolus.

A-2625. Nothrotheriops shastensis

$11,610 \pm 60$

Single dung bolus.

A-2626. Nothrotheriops shastensis

$10,650 \pm 220$

Single dung bolus.

\section{A-2627. Nothrotheriops shastensis}

$11,060 \pm 240$

Single dung bolus.

A-2628. Nothrotheriops shastensis

$11,810 \pm 70$

Single dung bolus.

\section{4. * Oak Haven}

Oak Haven (NAU QSP site 881; NPS GLCA Accession 82) is a small shelter at $1188 \mathrm{~m}$ elevation with a north-northwest aspect, directly across from Mammoth Alcove. The site contains the remnants of stratified layers. Collected near the surface, a sample of Quercus gambelii was ${ }^{14} \mathrm{C}$ dated to $9180 \pm 100$ (Beta-28929), with Rosa woodsii twigs, a unit below, to $11,690 \pm 120$ (Beta-25418). Between the Quercus and the Rosa were dung of Mammuthus, Bison and "Euceratherium"; although all were dated by association, each species could be, and should be, dated directly. Withers (1989) and Withers and Mead (ms.) have studied the plant macrofossils; however, the site needs more detailed study. This site is included in this list to indicate that material is available for future detailed ${ }^{14} \mathrm{C}$ analysis.

\section{Oakleaf Alcove}

Oakleaf Alcove is in Lake Canyon, $0.4 \mathrm{~km}$ up-canyon from the original confluence with the Colorado River, and is now submerged under Lake Powell (GLCA). The shelter (archaeological site 42SA374) was heavily vandalized prior to the archaeological survey and testpit analyses in the early 1960s. Martin and Sharrock (1964) reported on human coprolites from various shelters, including Oakleaf Alcove. The single Equus (horse) bolus was analyzed for pollen (200 grain count; $43 \%$ Betula and 39\% Artemisia) and was ${ }^{14} \mathrm{C}$ dated (see A-526, below; Haynes, Damon \& Grey 1966). Martin (personal communication 1990) indicates that the identification of the bolus as Equus is a best-estimate based on the level of identification of Pleistocene dung during the early 1960s. The specimen was so similar to horse dung, there was some doubt that it was a fossil. The ${ }^{14} \mathrm{C}$ analysis consumed the entire sample. Our experience is that the only other animal that would produce a bolus similar in appearance to a horse is Nothrotheriops, assuming that the horse dung contents were browse remains. The sloth is an unlikely candidate, given the local topography in the region of the alcove. Sometimes highly fragmented Mammuthus dung appears vaguely similar to a graze-diet horse bolus.

A-526. Equus

$24,600 \pm 1400$

A single bolus of dung. 


\section{Rampart Cave}

Rampart Cave (NAU QSP site 9128; NPS GRCA Accession 4597) is a small limestone cave at $525 \mathrm{~m}$ elevation with a north-facing entrance. The deposit was discovered and test pits excavated in the 1930s. A trench was dug in 1941. Publications about this site include reports on the faunal remains (Wilson 1942), Nothrotheriops shastensis dung (Hansen 1978; Long, Hansen \& Martin 1974; Laudermilk \& Munz 1938; Long \& Martin 1974; Martin, Sabels \& Shutler 1961; Martin, Thompson \& Long 1985; Thompson et al. 1980), Oreamnos harringtoni (Mead 1983; Mead et al. 1986b), and packrat middens (Phillips 1977, 1984; Phillips \& Van Devender 1974; Van Devender, Phillips \& Mead 1977). In 1976, fire destroyed all but a small section of the deposit. Faunal remains (skeletal, hide/hair, keratin and dung) can be found at the Department of Paleobiology, Smithsonian Institution, Washington, DC, the Desert Laboratory, The University of Arizona and in the GRCA collection.

\section{A-1041. Nothrotheriops shastensis}

$11,480 \pm 200$

Trampled dung mass from $0-5 \mathrm{~cm}$ depth.

\section{A-1042. Nothrotheriops shastensis}

$>40,000$

Bolus from $132 \mathrm{~cm}$ depth.

Bolus from $99 \mathrm{~cm}$ depth.

A-1066. Nothrotheriops shastensis

Bolus from the surface.

A-1067. Nothrotheriops shastensis

$10,780 \pm 200$

Bolus from the surface.

A-1068. Nothrotheriops shastensis

Bolus from the surface.

A-1070. Nothrotheriops shastensis

Bolus from $61 \mathrm{~cm}$ depth.

A-1207. Nothrotheriops shastensis

Bolus from $67 \mathrm{~cm}$ depth.

A-1210. Nothrotheriops shastensis

Bolus from $99 \mathrm{~cm}$ depth.

\section{A-1278. Oreamnos harringtoni}

$18,430 \pm 300$

Pellets from $91 \mathrm{~cm}$ depth. Eight keratinous hornsheaths of the extinct mountain goat from various levels were dated by AMS; ages span 10,140 to 28,700 (Mead et al. 1986b). 
A-1318. Nothrotheriops shastensis

$12,470 \pm 170$

Bolus from an unknown location; possibly the same as sample I-442, but the date does not verify this.

A-1392. Nothrotheriops shastensis

$11,370 \pm 300$

Trampled bolus at $0-5 \mathrm{~cm}$ depth.

A-1395. Nothrotheriops shastensis

$11,160 \pm 130$

Bolus from an unknown location.

A-1453. Nothrotheriops shastensis

$11,140 \pm 250$

Bolus secondarily deposited into a packrat midden.

A-1602. Nothrotheriops shastensis

$11,090 \pm 190$

Bolus from the surface, unprovenienced location.

A-2174. Nothrotheriops shastensis

$10,500 \pm 180$

Bolus from an unknown location.

I-442. Nothrotheriops shastensis

$10,400 \pm 275$

Bolus from the surface, unknown location.

L-473A. Nothrotheriops shastensis

$10,035 \pm 250$

Trampled bolus at 0-5 cm depth. Martin, Thompson and Long (1985) suggest Neotoma contamination of this "young" sample.

\section{L-473C. Nothrotheriops shastensis}

$12,050 \pm 400$

Bolus from $46 \mathrm{~cm}$ depth.

\section{7. * Sandblast Cave}

Sandblast Cave (GRCA) is a series of three caverns that merge together to form a small cave complex. Locality A contains packrat middens and Gymnogpys bones and nesting materials (Emslie 1987, 1988). Locality B is a profiled fissure fill of sediments containing stratified layers of dung.

Beta-28793. Oreamnos harringtoni

$>\mathbf{3 3 , 1 0 0}$

Dung pellets from layer 1. $0.2 \mathrm{~g}$ of $\mathrm{C}$ was recovered from the pellets and were given extended counting time.

Beta-28794. Oreamnos harringtoni

$>29,900$

Dung pellets from layer 3. $0.6 \mathrm{~g}$ of $\mathrm{C}$ was recovered from the pellets and were given extended counting time.

\section{8. * Shrubox Alcove}

Shrubox Alcove (NAU QSP site 882; NPS GLCA Accession 82) faces north-northwest at $1204 \mathrm{~m}$ 
elevation. The dripline is such that very little width of the deposit is preserved in this wide shelter. Overlying the laminated lacustrine and fluvial units are eolian and roof spall layers, where Quercus and dung pellets of "Euceratherium collinum" have been recovered. Oak twigs were dated (from bottom to top): Beta-25413: 23,100 \pm 660 (1 twig); Beta-25416: 12,690 \pm 180 (2 twigs, 0.5 gm C, associated with Bison, "Euceratherium", and cf. Ovis dung), and Beta-25656: $8830 \pm 190(0.25$ gm C, with associated Mammuthus). Withers (1989) and Withers and Mead (ms.) provided paleobotanical and paleoenvironmental data. Dung samples of "Euceratherium," Bison, Oreamnos, Ovis and Mammuthus have been identified from this site, but not dated.

\section{Stanton's Cave}

Stanton's Cave (NAU QSP site 9121; NPS GRCA Accession 4597; archaeological site Ariz. C:5:3) is a large solution cavern in the Redwall Formation of the Grand Canyon (Euler 1984). The cave, at $927 \mathrm{~m}$ elevation, is $44 \mathrm{~m}$ above the present river level and has an eastern aspect. An archaeological excavation in the late 1960s for the split-twig figurines uncovered voluminous Pleistocene floral and fauna remains. Stratified sediments traverse the Holocene to the Holocene/Pleistocene boundary. Presently, Ovis canadensis lives in the area, as it apparently did throughout the Holocene. Initial studies of the stratified sediments containing dung pellets considered the "small pellets" to be from Ovis and the "large pellets" from the extinct Oreamnos harringtoni (Robbins, Martin \& Long 1984). No "large pellets" were found above the $20-\mathrm{cm}$ level in the stratified section. The identifications below are based on conclusions in Robbins, Martin and Long (1984) and Mead, O'Rourke \& Foppe (1986). Euler (1984) includes numerous articles on various aspects of the cave and its contents. Mead et al. (1986b) present AMS dates of the hornsheaths of Oreamnos $(\mathrm{n}=15)$, and Mead et al. $(1991)$ offer AMS dates and stable carbon/nitrogen isotope ratios of Ovis $(\mathrm{n}=3)$ and Oreamnos. We curated most of the skeletal remains for the NPS.

\section{A-1132. Oreamnos harringtoni}

$13,700 \pm 500$

Large pellets from $20-25 \mathrm{~cm}$ depth.

\section{A-1155. Oreamnos harringtoni}

$10,870 \pm 200$

Large pellets from $20-25 \mathrm{~cm}$ depth.

\section{A-1167. Oreamnos harringtoni}

$12,980 \pm 200$

Large pellets from $25-30 \mathrm{~cm}$ depth.

\section{A-1168. Oreamnos harringtoni}

$15,500 \pm 600$

Large pellets from $35-40 \mathrm{~cm}$ depth.

\section{A-1246. Oreamnos harringtoni}

$17,300 \pm 800$

Large pellets from $55-60 \mathrm{~cm}$ depth.

Comment: ${ }^{14} \mathrm{C}$ analyses on small pellets date to $<11$ ka (Robbins, Martin \& Long 1984).

\section{0. * Withers Wallow}

Withers Wallow (NAU QSP site 883; NPS GLCA Accession 82) is a sandstone shelter at $1220 \mathrm{~m}$ elevation with a north-northwest aspect. This site contains remnant deposits of laminated fluvial and lacustrine sediments. The south end of the shelter contains a small area of deflating eolian, 
semicompacted sand with plant debris and dung of $c f$. Ovis, Bison, and Mammuthus. No described profiles exist nor has there been a formal excavation at this site.

Beta-25419. Mammuthus

$12,010 \pm 160$

Three small fragments of what appeared to be a single, crushed dung bolus were recovered from the loose sand profile. Only one fragment was dated.

\section{COMPILATIONS}

Table 1 shows 20 localities from the Colorado Plateau that contain dung of megaherbivores, along with other dung types and biotic remains. Seven species of megaherbivores were identified utilizing

TABLE 1. Animal species represented by dung remains from 20 localities on the Colorado Plateau

\begin{tabular}{|c|c|c|c|c|c|c|c|c|c|c|c|c|}
\hline & & $\begin{array}{l}\dot{0} \\
\dot{0} \\
5 \\
\dot{0} \\
\dot{0}\end{array}$ & 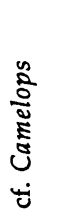 & \begin{tabular}{l}
$\dot{0}$ \\
के \\
\multirow{3}{5}{} \\
离
\end{tabular} & 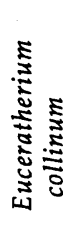 & 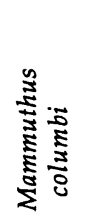 & 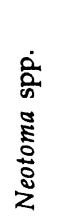 & 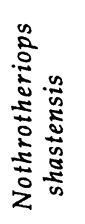 & 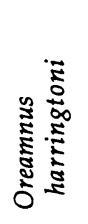 & 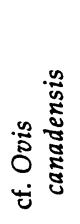 & 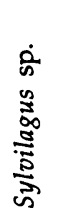 & 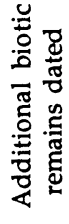 \\
\hline 1 & Bare Ladder Shelter & - & - & - & - & - & * & - & * & - & - & * \\
\hline 2 & Bechan Cave & - & - & $?$ & * & * & ** & ** & $?$ & $* *$ & $* *$ & $*$ \\
\hline 3 & BF Alcove & - & $* *$ & - & - & - & - & - & - & - & - & * \\
\hline 4 & Bida Cave & - & - & - & - & - & $* *$ & - & * & $* *$ & - & * \\
\hline 5 & Chuar Cave & - & - & - & - & - & - & - & * & - & - & - \\
\hline 6 & Cottonwood Alcove & - & - & - & * & - & - & - & - & - & - & - \\
\hline 7 & Cowboy Cave ${ }^{+}$ & * & - & $?$ & - & $* ?$ & $* *$ & $* *$ & - & - & - & * \\
\hline 8 & Disappearing Cave & - & - & - & - & - & - & - & * & - & - & * \\
\hline 9 & Grobot Grotto & $* *$ & - & - & * & * & $* *$ & - & $?$ & $* *$ & - & * \\
\hline 10 & Hooper's Hollow & * & - & - & $* *$ & - & ** & - & $?$ & $* *$ & - & * \\
\hline 11 & Kaetan Cave & - & - & - & - & - & - & - & * & - & - & * \\
\hline 12 & Mammoth Alcove & $* *$ & - & - & - & * & - & - & - & $* *$ & - & * \\
\hline 13 & Muav Caves & - & - & - & - & - & - & * & - & - & - & - \\
\hline 14 & Oak Haven & $* *$ & - & - & $* *$ & $* *$ & - & - & - & - & - & * \\
\hline 15 & Oakleaf Alcove & - & - & $*$ & - & - & - & - & - & - & - & * \\
\hline 16 & Rampart Cave & - & - & $* *$ & - & - & * & * & * & $* *$ & $* *$ & * \\
\hline 17 & Sandblast Cave & $* *$ & $* *$ & $* *$ & - & - & - & - & * & - & - & * \\
\hline 18 & Shrubox Alcove & ** & - & - & $* *$ & $* *$ & - & - & $* * ?$ & $* *$ & - & * \\
\hline 19 & Stanton's Cave & ** & - & $* *$ & - & - & $* *$ & - & * & * & - & * \\
\hline 20 & Wither's Wallow & ** & - & - & - & * & - & - & - & $* *$ & - & * \\
\hline \multicolumn{2}{|c|}{$\begin{array}{r}\text { Number of directly } \\
\text { dated occurrences }\end{array}$} & 2 & 0 & 1 & 3 & $4-5$ & 2 & 2 & 8 & 1 & 0 & 17 \\
\hline
\end{tabular}

*Directly ${ }^{14} \mathrm{C}$ dated; ** Species present at the site but not directly ${ }^{14} \mathrm{C}$ dated; some remains are only skeletal. ${ }^{\dagger}$ See text for discussion. 
dung: Bison, Equus, "Euceratherium," Mammuthus, Nothrotheriops, Oreamnos and Ovis, and 79 ${ }^{14} \mathrm{C}$ dates were measured from the sites. Dates on extinct herbivores, from only three sites, BF Alcove, Oak Haven, and Shrubox Alcove, were not directly measured on dung remains. Most sites contain additional associated ${ }^{14} \mathrm{C}$ and $\mathrm{U} / \mathrm{Th}$ dates on skeletal and botanical remains.

Figure 3 illustrates the number of ${ }^{14} \mathrm{C}$ dates on megafaunal species based on dung analyses. The most detailed temporal record of ${ }^{14} \mathrm{C}$-dated dung is from the extinct mountain goat, Oreamnos harringtoni. A similar record is held for keratinous hornsheaths of the same species (Mead et al. 1986b). Additional ${ }^{14} \mathrm{C}$ analyses are more likely to provide a more detailed chronology of the occurrence of the mountain goat, than a particular age. The chronological records of Mammuthus and Nothrotheriops are not as temporally complete as those of Oreamnos. However, the strategy for dating these two species was to provide detail on the "last" occurrence in each deposit.

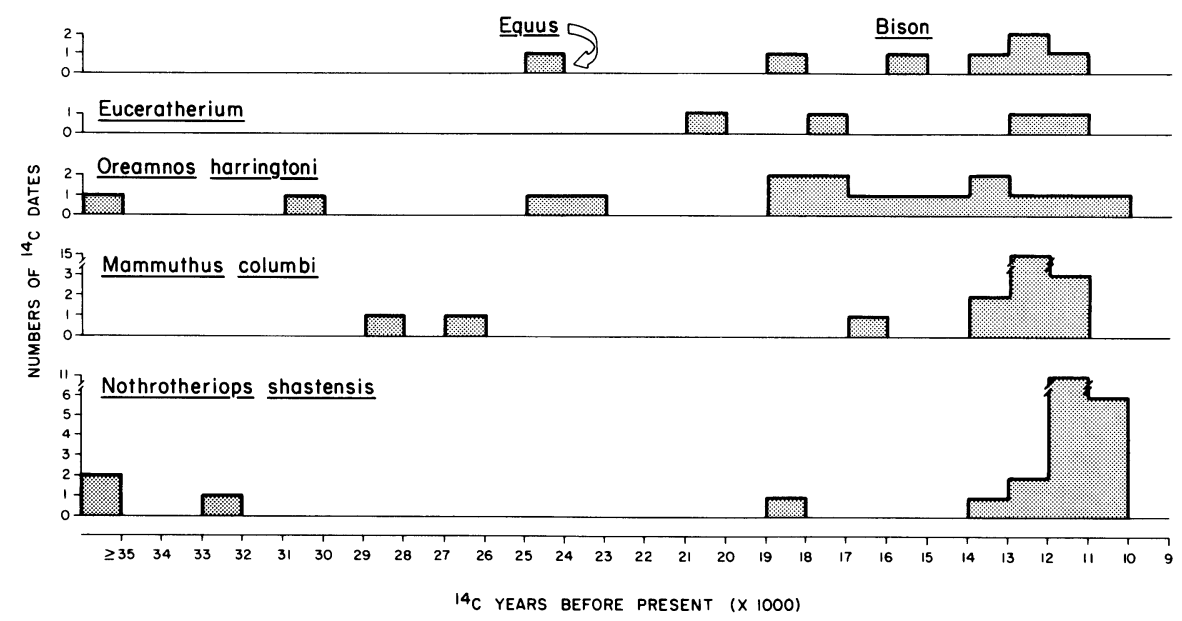

Fig. 3. Numbers of ${ }^{14} \mathrm{C}$ ages directly on Pleistocene dung by millennium. Pleistocene species younger than 10 ka BP have not been ${ }^{14} \mathrm{C}$ analyzed. See text for discussion.

\section{END OF THE PLEISTOCENE}

In recent reviews of the chronology of North American late Pleistocene extinctions, Grayson (1989, 1991) indicated that 35 genera of late Pleistocene mammals became extinct at or by the end of the Wisconsin Glacial (see also Martin \& Klein 1984; Martin 1987). Grayson used various ${ }^{14} \mathrm{C}$ results in a review of the "quality" of dates (in a compilation of 363 determinations; Mead \& Meltzer 1984; Meltzer \& Mead 1985). These authors also established a rating system to determine whether or not a particular ${ }^{14} \mathrm{C}$ date was suitable for use as a direct age for a particular species. The twopart rating was from 0 to 9 , and those dates rating 8 or 9 were considered suitable or "good" (Grayson 1989, 1991) for use in extinction analyses. Grayson (1989) determined that, of the 35 extinct genera, only 9 taxa contained good dates: Camelops (camel), Equus, Glossotherium (= Paramylodon, ground sloth), Mammut (mastodont), Mammuthus, Megalonyx (giant ground sloth), Nothrotheriops, Smilodon (sabertooth), and Tapirus (tapir). Of these 9 taxa, only 7 have good ${ }^{14} \mathrm{C}$ dates for the terminal Wisconsin Glacial (omitting Glossotherium and Megalonyx).

All ${ }^{14} \mathrm{C}$ analyses on dung presented here rate 9 in the Meltzer and Mead (1985) system. On the Colorado Plateau, deposition of fecal remains of different types, attributed to various extinct or extrálocal large mammals, ceased within the same millennium (Fig. 3). ${ }^{14} \mathrm{C}$ dating of hornsheaths 
and dung of Oreamnos harringtoni provides a weighted average time of extinction of $11,160 \pm 125$ BP (Mead et al. 1986b). Weighted average ${ }^{14} \mathrm{C}$ dates of Mammuthus dung indicate an extinction time of $11,820 \pm 80$ BP. Previously, we indicated that a weighted time of extinction for the mammoth was $11,270 \pm 65 \mathrm{BP}$. However, that analysis included the possibly contaminated tusk date (AMS) from Professor Valley, Utah (Agenbroad \& Mead 1989). Our present, conservative approach uses the older of the two weighted average dates of dung samples only. Martin, Thompson and Long (1985) indicate a weighted average time of extinction for Nothrotheriops shastensis of $11,016 \pm 50 \mathrm{BP}$ on dung from a variety of deposits both on and adjacent to the Colorado Plateau.

Bison is last recorded in the deposits by the youngest ${ }^{14} \mathrm{C}$ date of $11,810 \pm 140$ from Cowboy Cave. However, it is not absolutely certain that Bison dung was the actual species analyzed for the age. A Bison keratinous hornsheath and hoof were AMS dated from Bison Alcove, Arches National Park, southeastern Utah (Mead, Sharpe \& Agenbroad 1991). The dates of $405 \pm 65$ and $355 \pm 60$ BP confirm the presence of this species on the Colorado Plateau during the late Holocene, but we do not know whether this species lived on the Plateau throughout the Holocene.

Ovis canadensis is known to have lived throughout the Colorado Plateau during the Holocene. Dung remains of this species from Stanton's Cave were ${ }^{14} \mathrm{C}$ dated (Robbins, Martin \& Long 1984). An AMS date on a hornsheath from this cave is 20,540 \pm 170 BP (Beta-29498, ETH-4818; Mead \& Meltzer, unpublished data), the oldest directly dated remains of this species on the Plateau. Other dates on Ovis in this series include 15,000, 12,500 and 1100 BP from both Rampart and Stanton's caves (Mead \& Meltzer, unpublished data).

Grayson $(1989,1991)$ states that it has become increasingly difficult to place a new taxon in the terminal Wisconsin. Although "Euceratherium" remains from the Colorado Plateau are not completely understood, dung attributed to this species has been ${ }^{14} \mathrm{C}$ dated no younger than 11,630 \pm 150 BP (Bechan Cave).

Although Bison sp. and Ovis canadensis avoided extinction and local extirpation, and persisted on the Colorado Plateau from the Wisconsin Glacial through the latest Holocene, Oreamnos harringtoni, "Euceratherium collinum," Mammuthus columbi and Nothrotheriops shastensis extirpated the region sometime between 11.8 and $11 \mathrm{ka}$ (using weighted averages of youngest ${ }^{14} \mathrm{C}$ dates). We feel that analysis of identified dung and keratinous remains are still considered the most reliable materials to ${ }^{14} \mathrm{C}$ date, when the initial question includes the application of the date to the time of local extirpation. The Colorado Plateau provides a unique preservation habitat, found in greater abundance of deposits and species richness than anywhere else in North America.

\section{ACKNOWLEDGMENTS}

We acknowledge and appreciate financial help from National Science Foundation grants EAR 8708287 and 8845217, National Park Service contract CX-1200-4-A062, and National Geographic Society grants $2711-83,3016-85$ and 3280-86. We appreciate the comments and help from Adrienne Anderson, Robert Schiller, Vic Vieirra, John Benjamin, Larry Belli, and numerous other National Park Service personnel, Paul S. Martin, Phil Geib, Emilee M. Mead, Austin Long, Richard Hansen, Kim Withers, Elizabeth Barnosky, numerous students in the Quaternary Studies Program, Northern Arizona University, Ken Cole, Tom Van Devender, Geoffrey Spaulding, Robert Euler, John Alexander, and several of the Nickens Associates of 1985-1986. We appreciate the editorial help from Paul S. Martin, Everett H. Lindsay and Renee Kra. Emilee M. Mead drafted the figures and took the photograph. 


\section{REFERENCES}

Agenbroad, L. D. and Mead, J. I. 1987 Late Pleistocene alluvium and megafauna dung deposits of the central Colorado Plateau. In Davis, G. and VandenDolder, E., eds., Geologic diversity of Arizona and its margins: excursions to choice areas. Arizona Bureau of Geology and Mineral Technology Special Paper 5: 68-85.

1989 Quaternary geochronology and distribution of Mammuthus on the Colorado Plateau. Geology 17: 861-864.

Agenbroad, L. D., Mead, J. I., Mead, E. M. and Elder, D. 1989 Archaeology, alluvium, and cave stratigraphy: the record from Bechan Cave, Utah. The Kiva 4: 335-351.

Cole, K. L. (ms.) 1981 Late Quaternary environments in the eastern Grand Canyon: Vegetational gradients over the last 25,000 years. Unpublished Ph.D. dissertation, The University of Arizona.

1982 Late Quaternary zonation of vegetation in the Grand Canyon. Science 217: 1142-1145.

1990 Late Quaternary vegetation gradients through the Grand Canyon. In Betancourt, J. L., Van Devender, T. R. and Martin, P. S., eds., Packrat Middens: The Last 40,000 Years of Biotic Change. Tucson, The University of Arizona Press: 240-256.

Cole, K. L. and Mead, J. I. 1981 Late Quaternary animal remains from packrat middens in the eastern Grand Canyon, Arizona. Journal of the ArizonaNevada Academy of Science 16: 24-25.

Davis, O. K., Agenbroad, L. D., Martin, P. S. and Mead, J. I. 1984 The Pleistocene dung blanket of Bechan Cave, Utah. In Genoways, H. H. and Dawson, M. R., eds., Contributions in Quaternary Vertebrate Paleontology: A Volume in Memorial to John E. Guilday. Carnegie Museum of Natural History Special Publication 8: 267-282.

Davis, O. K., Mead, J. I., Martin, P. S. and Agenbroad, L. D. 1985 Riparian plants were a major component of the diet of mammoths of southern Utah. Current Research in the Pleistocene 2: 81-82.

Emslie, S. D. 1987 Age and diet of fossil California condors in Grand Canyon, Arizona. Science 237: 768-770.

1988 Vertebrate paleontology and taphonomy of caves in Grand Canyon, Arizona. National Geographic Research 4: 128-142.

Euler, R. C. 1984 The archaeology, geology, and paleobiology of Stanton's Cave. Grand Canyon Natural History Association Monograph 6: 141 p.

Grayson, D. K. 1989 The chronology of North American late Pleistocene extinctions. Journal of Archaeological Science 16: 153-165.

1991 Late Pleistocene mammalian extinctions in North America: taxonomy, chronology, and explanations. Journal of World Prehistory 5: 193-231.

Hansen, R. M. 1978 Shasta ground sloth food habits, Rampart Cave, Arizona. Paleobiology 4: 302-319.
1980 Late Pleistocene plant fragments in the dungs of herbivores at Cowboy Cave. In Jennings, J. D., ed., Cowboy Cave. University of Utah, Anthropological Papers 104: 179-189.

Haynes, C. V., Damon, P. E. and Grey, D. C. 1966 Arizona radiocarbon dates VI. Radiocarbon 8: 1-21.

Jennings, J. D., ed. 1980 Cowboy Cave. University of Utah, Anthropological Papers 104: 224 p.

Laudermilk, J. D. and Munz, P. A. 1938 Plants in the dung of Nothrotherium from Rampart and Muav caves, Arizona. Carnegie Institute of Washington Publication 487: 271-281.

Long, A., Hansen, R. M. and Martin P. S. 1974 Extinction of the Shasta ground sloth. Geological Society of America Bulletin 85: 1843-1848.

Long, A. and Martin, P. S. 1974 Death of American ground sloths. Science 186: 638-640.

Lull, R. S. 1930 The ground sloth, Nothrotherium. American Journal of Science 20: 344-352.

Martin, P. S. 1987 Late Quaternary extinctions: the promise of TAMS ${ }^{14} \mathrm{C}$ dating. Nuclear Instruments and Methods B29: 179-186.

Martin, P. S. and Klein, R. G. 1984 Quaternary Extinctions: A Prehistoric Revolution. Tucson, The University of Arizona Press. 892 p.

Martin, P. S., Sabels, B. E. and Shutler, D. 1961 Rampart Cave coprolite and ecology of the Shasta ground sloth. American Journal of Science 259: 102-127.

Martin, P. S. and Sharrock, F. W. 1964 Pollen analysis of prehistoric human feces: a new approach to ethnobotany. American Antiquity 30: 168-180.

Martin, P. S., Thompson, R. S. and Long, A. 1985 Shasta ground sloth extinction: a test of the blitzkrieg model. In Mead, J. I. and Meltzer, D. J,. eds., Environments and Extinctions: Man in Late Glacial North America. Orono, University of Maine. 5-14.

Mead, J. I. (ms.) 1983 Harrington's extinct mountain goat (Oreamnos harringtoni) and its environment in the Grand Canyon, Arizona. Unpublished Ph.D. dissertation, The University of Arizona.

Mead, J. I. and Agenbroad, L. D. 1989 Pleistocene dung and the extinct herbivores of the Colorado Plateau, southwestern USA. Cranium 6: 29-44.

Mead, J. I., Agenbroad, L. D., Davis, O. K. and Martin, P. S. 1986a Dung of Mammuthus in the arid Southwest, North America. Quaternary Research 25: 121127.

Mead, J. I., Agenbroad, L. D., Martin, P. S. and Davis, O. K. 1984 The mammoth and sloth dung from Bechan Cave in southern Utah. Current Research in the Pleistocene 1: 79-80.

Mead, J. I., Agenbroad, L. D., Phillips, A. M. and Middleton, L. T. 1987 Extinct mountain goat (Oreamnos harringtoni) in southeastern Utah. Quaternary Research 27: 323-331.

Mead, J. I., Martin, P. S., Euler, R. C., Long, A., Jull, A. J. T., Toolin, L. J., Donahue, D.J. and Linick, T. 
W. 1986b Extinction of Harrington's mountain goat. Proceedings of the National Academy of Science 83: 836-839.

Mead, J. I. and Meltzer, D. J. 1984 North American late Quaternary extinctions and the radiocarbon record. In Martin, P. S. and Klein, R. G., eds., Quaternary Extinctions: A Prehistoric Revolution. Tucson, The University of Arizona Press: 440-450.

Mead, J. I., Meltzer, D. J., Vogel, J. C. and Lawler, M. C. 1991 Stable carbon and nitrogen isotope ratios of late Pleistocene Ovis and Oreamnos from the Grand Canyon, Arizona. Abstract. Journal of the ArizonaNevada Academy of Science, Supplement: 28 p.

Mead, J. I., O'Rourke, M. K. and Foppe, T. M. 1986 Dung and diet of the extinct Harrington's mountain goat (Oreamnos harringtoni). Journal of Mammalogy 67: 284-293.

Mead, J. I., Sharpe, S. E. and Agenbroad, L. D. 1991 Holocene bison from Arches National Park, southeastern Utah. The Great Basin Naturalist 51: 336342.

Meltzer, D. J. and Mead, J. I. 1985 Dating late Pleistocene extinctions: theoretical issues, analytical bias, and substantive results. In Mead, J. I. and Meltzer, D. J., eds., Environments and Extinctions: Man in Late Glacial North America. Orono, University of Maine: 145-173.

O'Rourke, M. K. and Mead, J. I. 1985 Late Pleistocene and Holocene pollen records from two caves in the Grand Canyon. In Fall, P., Jacobs, B. and Davis, 0. K., eds., American Association of Stratigraphic Palynologists 16: 169-186.

Phillips, A. M. (ms.) 1977 Packrats, plants and the Pleistocene in the lower Grand Canyon. Unpublished $\mathrm{Ph} . \mathrm{D}$. dissertation, The University of Arizona. 1984 Shasta ground sloth extinction. In Martin, P.
S. and Klein, R. G., eds., Quaternary Extinctions: $A$ Prehistoric Revolution. Tucson, The University of Arizona Press: $148-158$.

Phillips, A. M. and Van Devender, T. R. 1974 Pleistocene packrat middens from the lower Grand Canyon of Arizona. Journal of the Arizona Academy of Science 9: 117-119.

Robbins, E. I., Martin, P. S. and Long, A. 1984 Paleoecology of Stanton's Cave, Grand Canyon, Arizona. In Euler, R. C., ed., The archaeology, geology, and paleobiology of Stanton's Cave. Grand Canyon Natural History Association 6: 115-130.

Schwartz, D. W., Lange, A. L. and DeSaussure, R. 1958 Split-twig figurines in the Grand Canyon. American Antiquity 23: 264-274.

Thompson, R. S., Van Devender, T. R., Martin, P. S., Foppe, T. and Long, A. 1980 Shasta ground sloth (Nothrotheriops shastense Hoffstetter) at Shelter Cave, New Mexico: Environment, diet, and extinction. Quaternary Research 14: 360-376.

Van Devender, T. R., Phillips, A. M. and Mead, J. I. 1977 Late Pleistocene reptiles and small mammals from the lower Grand Canyon of Arizona. Southwestern Naturalist 22: 49-66.

Wilson, R. W. 1942 Preliminary study of the fauna of Rampart Cave, Arizona. Contributions to Paleontology, Carnegie Institution Publication 530: 169185.

Withers, K. (ms.) 1989 Late Quaternary vegetation and climate of Forty-Mile Canyon and Willow Gulch, in the central Colorado Plateau. M.S. thesis, Northern Arizona University.

Withers, K. and Mead, J. I. (ms.) Late Quaternary vegetation and climate in the Escalante River Basin, on the central Colorado Plateau. Submitted to Great Basin Naturalist. 